\title{
Climate benefits of U.S. EPA programs and policies that reduced methane emissions 1993-2013
}

\section{Authors:}

April M. Melvin, ${ }^{1}$ Marcus C. Sarofim, ${ }^{2 *}$ Allison R. Crimmins ${ }^{2}$

Author Affiliations:

${ }^{1}$ AAAS S\&T Policy Fellow hosted by the Climate Change Division, U.S. Environmental Protection Agency, Washington, DC 20460, USA

${ }^{2}$ Climate Change Division, U.S. Environmental Protection Agency U.S. Environmental

Protection Agency, Washington, DC 20460, USA

\section{*Corresponding Author:}

Marcus C. Sarofim

Climate Change Division

U.S. Environmental Protection Agency

1200 Pennsylvania Ave. NW

Washington, DC 20460, USA

Phone: (202) 343-9993

Email: sarofim.marcus@epa.gov

Number of pages: 5 


\section{Supporting Information}

Steps and equations for estimation of radiative forcing and change in global mean air temperature for methane $\left(\mathrm{CH}_{4}\right)$ :

1. Radiative forcing ( $\Delta \mathrm{F}$ in equation) due to reduced $\mathrm{CH}_{4}$ emissions was calculated using the simplified expression provided in Myhre et al. ${ }^{1}$ :

$\Delta \mathrm{F}=\alpha\left(\sqrt{ } \mathrm{M}-\sqrt{ } \mathrm{M}_{0}\right)-\left(\mathrm{f}\left(\mathrm{M}, \mathrm{N}_{0}\right)-\mathrm{f}\left(\mathrm{M}_{0}, \mathrm{~N}_{0}\right)\right) \quad$ (equation 1$)$

Where:

$\alpha=0.036$

$\mathrm{f}(\mathrm{M}, \mathrm{N})=0.47 \ln \left[1+2.01 \times 10^{-5}(\mathrm{MN})^{0.75}+5.31 \times 10^{-15} \mathrm{M}(\mathrm{MN})^{1.52}\right]$

$\mathrm{M}$ is the counterfactual $\mathrm{CH}_{4}$ concentration in $\mathrm{ppb}$

$\mathrm{M}_{0}$ is the observed $\mathrm{CH}_{4}$ concentration in $\mathrm{ppb}$

$\mathrm{N}_{0}$ is the observed $\mathrm{N}_{2} \mathrm{O}$ in $\mathrm{ppb}$

2. $\Delta \mathrm{F}$ values were multiplied by 1.65 to account for forcing resulting from the production of tropospheric $\mathrm{O}_{3}$ and stratospheric water vapor during the degradation of $\mathrm{CH}_{4}$ in the atmosphere. ${ }^{1}$

3. Radiative forcing estimates obtained from steps 1 and 2 were then used to determine the change in global mean air temperature $(\Delta \mathrm{T})$ attributed to reduced $\mathrm{CH}_{4}$ emissions using an equation provided by Shine et al. ${ }^{2}$ : 
$\Delta T(t)=1 / C \int_{0}^{t} \Delta F\left(t^{\prime}\right) \exp \left(\left(t^{\prime}-t\right) /(\lambda C)\right) d t^{\prime}$

(equation 2)

Where:

$\mathrm{C}$ is the heat capacity, $4.2 \times 10^{8} \mathrm{~J} \mathrm{~K}^{-1} \mathrm{~m}^{-2}$

$\lambda$ is the climate sensitivity

We use $\lambda$ consistent with a best estimate of climate sensitivity of $3^{3}$ and bounds of 1.5 and $4.5^{4}$

Steps and equations for estimation of radiative forcing and change in global mean air temperature for carbon dioxide $\left(\mathrm{CO}_{2}\right)$ :

1. Using the assumption that all $\mathrm{CH}_{4}$ accounted for in this analysis would become $\mathrm{CO}_{2}$ immediately, we calculated an immediate increase in atmospheric loading of $\mathrm{CO}_{2}$ equal to $44 / 16$ times the mass of the $\mathrm{CH}_{4}$. The lifetime of $\mathrm{CO}_{2}$ for these purposes was assumed to be 12.4 years (which is the $\mathrm{CH}_{4}$ lifetime ${ }^{1}$ ) as that is the time period in which the $\mathrm{CO}_{2}$ would have been created in any case due to oxidation of the $\mathrm{CH}_{4}$. Factors due to the carbon cycle itself, or reductions of $\mathrm{CO}_{2}$ in the future resulting from earlier absorption of the emitted $\mathrm{CO}_{2}$, were not accounted for, and would likely lead to a reduction in the impact calculated here.

2. Radiative forcing was calculated using the equation from Myhre et al. ${ }^{1}$ :

$$
\Delta \mathrm{F}=\alpha \ln \left(\mathrm{C} / \mathrm{C}_{0}\right)
$$

Where: 
$\alpha=5.35$

$\mathrm{C}$ is the counterfactual $\mathrm{CO}_{2}$ concentration in ppm

$\mathrm{C}_{0}$ is the observed $\mathrm{CO}_{2}$ concentration in ppm

Global mean $\mathrm{CO}_{2}$ concentration data from $\mathrm{NOAA}^{5}$ were used for observed concentrations.

3. Global mean air temperature changes were calculated using the same approach described for $\mathrm{CH}_{4}$.

\section{References}

1. Myhre, G.; Schindell, D.; Breon, F.-M.; Collins, W.; Fuglestvedt, J.; Huang, J.; Koch, D.; -F., L. J.; Lee, D.; Mendoza, B.; Nakajima, T.; Robock, A.; Stephens, G.; Takemura, T.; Zhang, H., Anthropogenic and natural radiative forcing. In Climate Change 2013: The Physical Science Basis. Contribution of Working Group I to the Fifth Assessment Report of the Intergovernmental Panel on Climate Change, Stocker, T. F.; Qin, D.; Plattner, G.-K.; Tignor, M.; Allen, S. K.; Boschung, J.; Nauels, A.; Xia, Y.; Bex, V.; Midgley, P. M., Eds. Cambridge University Press: Cambridge, United Kingdom and New York, NY, USA, 2013.

2. Shine, K. P.; Fuglestvedt, J. S.; Hailemariam, K.; Stuber, N., Alternatives to the global warming potential for comparing climate impacts of emissions of greenhouse gases. Climatic Change 2005, 68, (3), 281-302.

3. Meehl, G. A.; Stocker, T. F.; Collins, W. D.; Friedlingstein, P.; Gaye, A. T.; Gregory, J. M.; Kitoh, A.; Knutti, R.; Murphy, J. M.; Noda, A.; Raper, S. C. B.; Watterson, I. G.; Weaver, A. 
J.; Zhao, Z.-C., Global climate projections. In Climate Change 2007: The Physical Science Basis. Congribution of Working Group I to the Fourth Assessment Report of the Intergovernmental Panel on Climate Change, Solomon, S.; Qin, D.; Manning, M.; Chen, Z.;

Marquis, M.; Averyt, K. B.; Tignor, M.; Miller, H. L., Eds. Cambridge University Press:

Cambridge, United Kingdom and New York, NY, USA, 2007.

4. Collins, M.; Knutti, R.; Arblaster, J.; Dufresne, J.-L.; Fichefet, T.; Friedlingstein, P.; Gao, X.; Gutowski, W. J.; Johns, T.; Krinner, G.; Shongwe, M.; Tebaldi, C.; Weaver, A. J.; Wehner, M., Long-term climate change: projections, commitments and irreversibility. In Climate Change 2013: The Physcial Science Basis. Contribution of Working Group I to the Fifth Assessment Report of the Intergovernmental Panel on Climate Change, Stocker, T. F.; Qin, D.; Plattner, G.K.; Tignor, M.; Allen, S. K.; Boschung, J.; Nauels, A.; Xia, Y.; Bex, V.; Midgley, P. M., Eds. Cambridge University Press: Cambridge, United Kingdom and New York, NY, USA, 2013. 5. National Oceanic \& Atmospheric Administration, Earth System Research Laboratory, global greenhouse gas reference network; http://www.esrl.noaa.gov/gmd/ccgg/trends/global.html 